\title{
Ciemne strony modernizacji. Państwo i nauka wobec problemów spo- tecznych i narodowych. Recenzja książki Eugenika - biopolityka - państwo. Z historii europejskich ruchów eugenicznych w pierwszej po- towie XX w., red. M. Gawin, K. Uzarczyk, Wydawnictwo Neriton, Instytut Historii PAN, Warszawa 2010, ss. 324, z ilustracjami
}

$\mathrm{P}$ ublikacja wydawnictwa Neriton i Instytutu Historii PAN jest rezultatem międzynarodowej konferencji naukowej pt. Eugenics, Biopolitics and State zorganizowanej w 2008 roku w Warszawie przez Kancelarię Prezydenta RP oraz Instytut Historii Polskiej Akademii Nauk. Praca ma zatem charakter zbioru wypowiedzi; składa się na nią kilkanaście artykułów autorstwa naukowców różnych narodowości. Zebrane teksty, umieszczone w pięciu większych rozdziałach tematycznych, prezentują regionalne i narodowe aspekty myśli eugenicznej w wybranych państwach europejskich. Eugenika, biopolityka i państwo, zagadnienia pojawiające się w tytule publikacji, wyznaczają szeroką i zarazem ciekawą perspektywę spojrzenia na różne przejawy historii ruchu eugenicznego w kontekście teorii biopolitycznej. Autorzy ukazują proces stopniowej medykalizacji dyskursu politycznego, który ściśle wiąże się z rozwojem nowoczesnego państwa. W prezentowanych artykułach zaznacza się także wyjątkowy alians etosu nauki i autorytetu władzy, rozumiany jako ważny element postępu i modernizacji.

Druga połowa XX wieku, która wyznacza zakres chronologiczny publikacji, jest okresem najintensywniejszego rozwoju eugeniki. Względna, bo niepozbawiona głosów krytycznych fascynacja tą nową dyscypliną naukową objęła nie tylko Stany Zjednoczone i Niemcy, ale większość krajów europejskich. W tym okresie przybrała ona instytucjonalne formy. Wiązało się to z powstawaniem licznych towarzystw eugenicznych oraz instytutów badawczych. Problematyka eugeniczna nie tylko była prezentowana na konferencjach i zjazdach naukowych, ale także została włączona do debaty politycznej i publicznej, co niekiedy owocowało konkretnymi ustawami i reformami społecznymi.

Spośród innych, niestety nielicznych polskich publikacji na temat eugeniki, omawiana praca wyróżnia się odmiennym, „geograficznym” ujęciem problemu. W otwierającym książkę artykule Eugenika peryferii w pierwszej połowie XX w. w kontekście polskim Magdalena Gawin wyjaśnia specyfikę takiego spojrzenia w kategoriach centrum i peryferii. W kontekście teorii eugenicznych kraje centralne to Francja, Anglia i Niemcy, natomiast peryferyjne, to opisane w publikacji kraje Europy Środkowej, Wschodniej i Południowej. W pięciu rozdziałach czytelnik znaj- 
dzie informacje na temat wybranych aspektów eugeniki, między innymi w Polsce, Bułgarii, Grecji, na Łotwie oraz we Włoszech, Portugalii i Hiszpanii. W wymienionych krajach teorie eugeniczne zostały zapożyczone, ale z czasem nabrały specyficznego, lokalnego charakteru. Na uwagę zasługuje wspomniana przez Autorkę różnica w rozwoju badań historiograficznych dotyczących eugeniki między krajami Zachodu, a krajami należącymi do tzw. bloku wschodniego. O ile, jak twierdzi Magdalena Gawin, badania nad historią eugeniki w krajach Europy Zachodniej i dotyczące tego obszaru są mocno zaawansowane, o tyle sytuacja byłych krajów bloku sowieckiego wygląda zupełnie inaczej. Jest to wynik zaniechania tego rodzaju badań na tym obszarze po II wojnie światowej, co, jak zaznacza Autorka, spowodowane było cenzurą i propagandą. „Propagandowy przekaz przypisujący rasizm, eugenikę byłym kolonialnym potęgom Wielkiej Brytanii, Belgii i Francji i „niemieckim nazistom" musiał być prosty i sugestywny, nie było w nim miejsca na ambiwalencję, cieniowanie postaw i ocen, którego wymagała problematyka lokalnych ruchów eugenicznych"(s.10). Dotyczyło to również Polski, gdzie wznowienie badań nad historią eugeniki nastąpiło dopiero w latach dziewięćdziesiątych XX wieku. Zestawienie historii eugeniki w krajach peryferyjnych nie tylko pokazuje regionalne i narodowe zabarwienia myśli eugenicznej, ale uświadamia także formy i kanały międzynarodowej transmisji idei oraz ich wzajemnego oddziaływania. Taka perspektywa daje pełniejszy obraz historii ruchów eugenicznych dzięki możliwym porównaniom, co niewątpliwie jest dużym atutem omawianej publikacji.

Pierwszy rozdział książki zatytułowany Teoria eugeniczna w kontekście międzynarodowym wprowadza czytelnika w historię eugeniki w Europie, pokazując przyczyny jej popularności oraz wskazując argumenty krytyki. Marius Turda, profesor Oxford Brooks Univesity, autor pierwszego z artykułów przedstawia proces, który nazywa stopniową nacjonalizacją eugeniki. Pokazuje, w jaki sposób początkowe uniwersalne wartości, do których odwoływali się eugenicy, zaczęły nabierać nacjonalistycznego, rasistowskiego charakteru. Proces ten przebiegał od dewizy „dla dobra ludzkości” po hasło „czystości organizmu narodowego”, co znalazło swój wyraz w powstaniu w 1925 roku Niemieckiej Ligi Odrodzenia Narodowego i Dziedziczności. Niewątpliwie, jak zaznacza Autor, wzrost tendencji nacjonalistycznych i jednoczesna popularność myśli eugenicznej miały związek ze „zranionym poczuciem narodowej tożsamości” (s. 32). Istotnym czynnikiem stymulującym te procesy była silna potrzeba odrodzenia narodowego, istniejąca w Europie po I wojnie światowej. W kontekście dziewiętnastowiecznych teorii degeneracji, które wciąż krążyły po Europie w środowiskach intelektualnych i publicystyce, eugeniczne metody poprawienia zdrowotnego stanu społeczeństwa zyskiwały coraz szersze poparcie i uznanie państwa „zatroskanego” o swój naród. Autor koncentruje się na negatywnej stronie eugeniki, z którymi wiążą się takie „użyteczne”, według eugeników działania jak 
sterylizacja, izolacja, eutanazja i wykluczenie chorych oraz obciążonych dziedzicznie. Obejmowały one również regulacje prawne dotyczące zawierania małżeństw i kontroli urodzeń. Owa „użyteczność” społeczna budziła jednak głosy krytyczne, zwłaszcza w środowiskach religijnych, ale także wśród naukowców i etyków. Najczęściej wskazywano na zbyt dużą ingerencję państwa w życie jednostki, dostrzegając w metodach eugenicznych formy dyskryminacji społecznej. W artykule zarysowany został także stosunek państw, świata nauki i poszczególnych kościołów do zadań, które stawiała sobie ta nowa dziedzina nauki. W kolejnym artykule tego rozdziału, Paul Weindling charakteryzuje debatę wokół teorii eugenicznej i jej zastosowań. Wymienia główne tendencje krytyczne wobec rasizmu i eugeniki, od momentu pojawienia się teorii Darwina do kontrowersji związanych z pojęciem rasy w debacie UNESCO w drugiej połowie XX wieku. Wskazuje także na dwa nuty sprzeciwu, jeden, który podważał naukowość eugeniki, i drugi mający charakter etyczno-religijny. Jak wynika z artykułu środowiska przeciwne eugenice były bardzo zróżnicowane pod względem ideologicznym i politycznym, w związku z tym trudno jednoznacznie wskazać, które były zdecydowanymi jej oponentami. Autor charakteryzuje również wybrane głosy krytyki wobec rasizmu oraz kształtowania się antyrasistowskich pojęć i języka aż do sformułowania przez Rafała Lemkina pojęcia ludobójstwa, określającego nazistowskie zbrodnie wojenne. W obu artykułach tego rozdziału poruszone zostały również niezwykle kontrowersyjne kwestie relacji między eugeniką a religią. Wynika z nich, że ambiwalentny stosunek do teorii i praktyk eugenicznych miały zarówno Kościoły protestanckie, jak i Kościół prawosławny, który próbował włączyć niektóre fragmenty eugeniki do swojej społecznej wizji. Niejednoznaczna była także, zdaniem Mariusa Turda, postawa Kościoła katolickiego, który mocno potępiał metody eugeniczne w zakresie prokreacji i małżeństwa, czego wyrazem była encyklika Piusa XI Casti Connubii z 1930 roku. Jednakże, jak stwierdza Autor „byłoby błędem uznanie, że credo eugeniczne zostało całkowicie odrzucone w kręgach katolickich”(s. 47). Niewątpliwie zagadnienie stosunku kościołów do eugeniki jest elementem szerszego problemu, wpisującego się w konflikt największych społecznych autorytetów: kościoła, nauki, państwa.

W rozdziale zatytułowanym Rasa $i$ engenika - narodowe recepcje engeniki przedstawione zostały różne aspekty oraz metody działań eugenicznych i rasowych w Bułgarii, Hiszpanii i Portugalii, na Łotwie oraz we Włoszech. Cztery artykuły, każdy poświęcony innemu obszarowi polityczno-geograficznemu, omawiają te elementy ruchu eugenicznego, które można uznać za specyficzne lub charakterystyczne dla danego kraju. W Bułgarii niemałe znaczenie w rozwoju myśli eugenicznej odgrywała teoria degeneracji społecznej, we Włoszech eugenika stała się argumentem na rzecz ekspansji faszystowskiej, na Łotwie była częścią oficjalnej polityki nacjonalistycznej reżimu Ulmanisa, a na Półwyspie Iberyjskim ideą, którą fascynowały 
się w duchu neomaltuzjańskim ruchy robotnicze i anarchistyczne, dyskutując między innymi na temat kontroli urodzeń i reformy seksualnej. Na szczególną uwagę w tym rozdziale zasługuje artykuł Francesco Cassata, opisujący publicystykę czasopisma Obrona rasy, ukazującego się we Włoszech czasów Mussoliniego. Czasopismo o charakterze propagandowym miało za zadanie kształtować świadomość rasową i jednocześnie legitymizować działania faszystów. Debaty, publikacje prasowe, ustawy zdrowotne oraz wszelkie instytucjonalne formy, które pojawiły się w wymienionych krajach, wskazują, że eugenika była uznana za pełnoprawną naukę, akceptowaną społecznie, propagowaną nie tylko przez naukowców i polityków, ale mającą także wsparcie różnych środowisk społecznych.

Głównym obszarem zainteresowań eugeników, zarówno tych, którzy byli zwolennikami metod pozytywnych, jak i tych, którzy optowali za bardziej radykalnymi środkami była kwestia walki z szeroko rozumianymi patologiami społecznymi. Kolejny rozdział książki, na który składają się dwa artykuły został poświęcony właśnie tej problematyce. Pierwszy z artykułów, na przykładzie sytuacji w Wiedniu podczas II wojny światowej, omawia nazistowską politykę zwalczania prostytucji, w ramach „oczyszczania” narodu i tak zwanej „ochrony zdrowia dziedzicznego”. W drugim tekście, autorka Sylwia Kuźma-Markowska charakteryzuje debatę wokół sterylizacji przestępców, chorych umysłowo i „dziedzicznie obciążonych”, która toczyła się w Polsce, głównie w okresie międzywojennym, ale z pewnymi reperkusjami jeszcze po II wojnie światowej. Warto dodać, że debata ta miała również swój praktyczny wymiar. Oba artykuły, choć dotyczą skrajnie różnych obszarów politycznych, ukazują w najbardziej dosadny sposób biopolityczny aspekt teorii i praktyk eugenicznych. Pod hasłami reform zdrowotnych państwa kryły się często represyjne regulacje prawne, pozwalające kontrolować życie jednostki. Proces wzmocnienia kontroli państwa przebiegał więc między innymi przez stopniową medykalizację różnych obszarów życia społecznego i indywidualnego, i obejmował także sferę seksualną człowieka.

Eugenika i nauka to tytuł kolejnego rozdziału recenzowanej publikacji, w którym zebrane zostały teksty poruszające kwestię wykorzystania myśli i metod eugenicznych w psychiatrii, pedagogice, kryminalistyce oraz genetyce w wybranych państwach „sfery peryferyjnej”. Z tego rodzaju działaniami, którym towarzyszyły dyskusje naukowców różnych profesji, wiązały się również konkretne działania polityczne i ustawodawcze. Na szczególną uwagę w tym rozdziale zasługuje artykuł omawiający kwestię opieki zdrowotnej i edukacyjnej nad dzieckiem w Grecji na początku XX wieku. Jest to jedyny tekst w omawianej publikacji, który przedstawia wyłącznie pozytywne aspekty myśli eugenicznej. Jak zaznacza Autorka Despina Karakatsani, w Grecji w latach trzydziestych, a więc w okresie największej popularności myśli eugenicznej nie wprowadzono „żadnych rozwiązań z zakresu eugeniki negatywnej"(s. 186). Wykorzystywana była ona tylko na rzecz edukacji i kampa- 
nii społecznej, propagującej wiedzę na temat higieny, zdrowia i wychowania jako elementów istotnych dla funkcjonowania społeczeństwa. Pozytywny aspekt greckiej myśli eugenicznej, która w dużej mierze zapożyczona została z Francji, wiązał się zdaniem Autorki, z warunkami politycznymi, niską świadomością społeczną dotyczącą dziedziczenia oraz z wcześniejszym rozwojem pedologii. W rozdziale tym zamieszczony został również artykuł omawiający historię intelektualnego życia wybitnego polskiego biologa z okresu międzywojennego Stanisława Skowrona, zwolennika eugeniki, który po trudnych doświadczeniach II wojny światowej poddał krytyce jej zasady i stał się zwolennikiem innych teorii genetycznych propagowanych wówczas przez Związek Radziecki.

Ostatni rozdział, najbardziej nowatorski ze względu na samo ujęcie problematyki eugenicznej, porusza kwestię stosunku mniejszości narodowych do eugeniki i związanych z nią teorii rasowych. Pierwszy z artykułów omawia sytuację mniejszości saksońskiej w Transylwanii, która mając na celu odrodzenie etniczne stała się adwokatem faszystowskiej eugeniki. W drugim artykule poświeconym mniejszości żydowskiej, Kamila Uzarczyk opisuje recepcję idei eugenicznych wśród lekarzy żydowskich w międzywojennej Polsce. Popularność koncepcji eugenicznych w tej społeczności wynikała również z idei ochrony tożsamości narodowej. Wiązało się to z potrzebą poprawy stanu zdrowia narodu i jego odrodzenia biologicznego, co znalazło wyraz w utworzonej w 1918 roku Sekcji Higieny Społecznej i Eugeniki przy Towarzystwie Ochrony Zdrowia Ludności Żydowskiej w Polsce. Rozdział jest pełen ciekawych spostrzeżeń, pokazujących niejednoznaczne oblicza funkcjonowania myśli eugenicznej.

Interesującym i wartym odnotowania uzupełnieniem publikacji są fotografie zamieszczone na ponad czterdziestu, ostatnich jej stronach. Dokumentują i obrazują one historię myśli eugenicznej w wymownej, czarno-białej konwencji. Plakaty, ryciny, fragmenty publikacji prasowych i projektów ustaw pochodzą z multimedialnej wystawy, która towarzyszyła wspomnianej już konferencji Eugenics, Biopolitics and State. W publikacji zamieszczone zostały także notki o autorach i redaktorkach książki, którymi są badaczki historii eugeniki: Magdalena Gawin, historyk pracujący w Instytucie Historii Polskiej Akademii Nauk, inicjatorka wystawy i autorka książki dotyczącej historii polskiego ruchu eugenicznego pt. Rasa i Nowoczesność. Historia polskiego ruchu engenicznego 1880-1953 oraz Kamila Uzarczyk, historyk, autorka książki Podstawy ideologiczne higieny ras i ich realizacja na przykładzie Ślaska $w$ latach 1924-1944, pracująca w Zakładzie Humanistycznych Nauk Lekarskich w Akademii Medycznej we Wrocławiu.

Publikacja Eugenika, biopolityka, państwo dostarcza wiele interesującego materiału dotyczącego historii ruchu eugenicznego w Europie. Nie było dotąd na polskim rynku wydawniczym publikacji, która w tak zróżnicowany i złożony sposób 
prezentowałaby historię eugeniki, ukazując jednocześnie jej niejednoznaczny charakter. Ogromna wartość merytoryczna oraz „międzynarodowa” bibliografia mogą być inspiracją dla dalszych komparatystycznych badań w tym zakresie. Jest to książka pokonferencyjna, cechuje ją specyficzny układ i szerokie spektrum poruszanej problematyki. Nie jest to zatem uporządkowana wykładnia z dziejów myśli eugenicznej. W niewielkim stopniu też czytelnik znajdzie informacje dotyczące historii eugeniki w Polsce. Niemniej jednak z kilku względów zasługuje ona na uwagę dydaktyków historii. Historia nauki jest właściwie tematem pobocznym w zakresie dydaktyki historii. Nie poświęca się jej wiele miejsca w podręcznikach, a zagadnienia tego rodzaju przedstawiane są najczęściej w ostatnim rozdziale, zdawkowo lub przy okazji innych ważnych politycznych problemów. Historia eugeniki zasługuje jednak na szczególną uwagę, łączy bowiem w sobie treści nie tylko z historii nauki, ale także z historii społecznej i historii idei politycznych. Stanowi również ważny element dziejów II wojny światowej i z tym okresem historii najczęściej jest wiązana. Mimo że początki eugeniki wiążą się z Anglią, krajem Franciszka Galtona, „ojca” koncepcji eugenicznych, to pierwsze, a więc uproszczone skojarzenia zawsze odwołują się do polityki rasowej i społecznej Trzeciej Rzeszy oraz nawiązują do problemu ludobójstwa. Omawiana publikacja może przełamać schematyczność ujęcia, pokazując ogólnoeuropejski charakter ruchu eugenicznego, jego złożoność, uświadamiając jednocześnie fakt, ,że idee mają konsekwencje”. Drugim ważnym elementem, na który warto zwrócić uwagę, jest owa „biopolityczność” eugeniki. Powiązana z rasowymi teoriami narodu i społeczeństwa w szczególny sposób łączyła sferę biologiczną człowieka z działaniami o charakterze politycznym i ideologicznym. Jej przykład pokazuje wzajemne przenikanie koncepcji politycznych i teorii naukowych oraz sposoby wykorzystywania tych ostatnich do celów czysto ideologicznych. Historia eugeniki zasługuje również na uwagę z tego względu, że w przejrzysty sposób poświadcza relacje związane z modernizacją państwa a rozwojem nauki, polegające na stopniowym poszerzaniu kontrolowanych obszarów życia indywidualnego i społecznego. W przekonaniu jej zwolenników eugenika miała dostarczyć rozwiązań dla piętrzących się problemów społecznych i narodowych. Miała też być metodą, która pozwoliłaby wyeliminować patologie społeczne. Stała się jednak w wielu przypadkach narzędziem kontroli, daleko ingerującym w życie jednostki. Eugenika była kwintesencją „,ducha epoki”, epoki postępu i modernizacji, która w poszczególnych lokalnych i narodowych przejawach nabierała odmiennych znaczeń. W edukacyjnym wymiarze książka skłania do refleksji nad etycznymi aspektami nauki oraz uświadamia jej społeczną funkcję. Może także uwrażliwić czytelnika na bezkrytyczne zawierzenie nauce $\mathrm{w}$ imię idei, w tym jednoznacznie rozumianego postępu. 